\title{
Sugarcane and Pine Biochar as Amendments for Greenhouse Growing Media for the Production of Bean (Phaseolus vulgaris L.) Seedlings
}

\author{
Charles L. Webber III ${ }^{1}$, Paul M. White Jr. ${ }^{1}$, Mengmeng Gu${ }^{2}$, Douglas J. Spaunhorst ${ }^{1}$, Isabel M. Lima ${ }^{3}$ \\ \& Eric C. Petrie ${ }^{1}$ \\ ${ }^{1}$ USDA, Agriculture Research Service, Sugarcane Research Unit, Houma, LA, USA \\ ${ }^{2}$ Department of Horticultural Sciences, Texas A\&M AgriLife Extension, College Station, TX, USA \\ ${ }^{3}$ USDA, Agriculture Research Service, Southern Regional Research Center, New Orleans, LA, USA \\ Correspondence: Charles L. Webber III, USDA, Agriculture Research Service, Sugarcane Research Unit, Houma, \\ LA 70360, USA. E-mail: chuck.webber@ars.usda.gov
}

Received: January 31, 2018

Accepted: March 1, $2018 \quad$ Online Published: March 15, 2018

doi:10.5539/jas.v10n4p58

URL: https://doi.org/10.5539/jas.v10n4p58

\begin{abstract}
Louisiana sugarcane farmers in 2016 harvested 11.7 million $\mathrm{Mg}$ of millable sugarcane from 163,000 ha, producing 1.47 million $\mathrm{Mg}$ of raw sugar and an estimated 3.5 million $\mathrm{Mg}$ of bagasse. Even though Louisiana sugar mills use $80 \%$ to $90 \%$ of the bagasse for fuel production, another 350,000 to $700,000 \mathrm{Mg}$ of bagasse accumulates each year. The conversion of the excess bagasse into biochar is one solution to reduce the excess supply. Research was conducted to determine the impact of sugarcane biochar as an amendment to soilless planting media for the production of green bean (Phaseolus vulgaris L.) seedlings. Sugarcane bagasse biochar (SBB) and pine biochar (PB) were each combined by volume with a commercial certified organic soilless growing media into 5 combinations ( $0 \%: 100 \%, 25 \%: 75 \%, 50 \%: 50 \%, 75 \%: 25 \%$, and 100\%:0\%, biochars and growing media, respectively). Green bean variety 'Bowie' seeds were planted in each of the different planting mixtures. The particle size distribution for the two biochars are in stark contrast to each other with the PB particle median, mean, geometric mean, and mode much greater than those of the SBB. As amendments to the soilless greenhouse growing media, the biochars (SBB and PB) functioned very well, especially at the $25 \%$ and $75 \%$ levels. The $100 \%$ SBB performed as well as the $100 \%$ commercial soilless growing media and slightly better than the $100 \%$ PB when comparing seedling fresh and dry weights. The $100 \%$ PB is not recommended as a soilless growing media even with the supplemental fertilizer used in these experiments. These results indicate that the volume of a standard soilless greenhouse growing media can be successfully extended by adding $25 \%$ to $75 \%$ SBB and PB without reducing bean seedling growth. Future research is needed to evaluate these biochars for the production of additional plant species.
\end{abstract}

Keywords: agricultural by-products, bagasse, certified organic, pine, soilless growing media, sugarcane

\section{Introduction}

Louisiana sugarcane farmers in 2016 harvested 11.7 million $\mathrm{Mg}$ of millable sugarcane from 163,000 ha, producing 1.47 million $\mathrm{Mg}$ of raw sugar and an estimated 3.5 million $\mathrm{Mg}$ of bagasse (American Sugar Cane League, 2017). Global sugar production in 2016 was over 170 million $\mathrm{Mg}$ of raw sugar, which resulted in the production of over 300 million $\mathrm{Mg}$ of bagasse at milling facilities (United States Department of Agriculture, 2017). Bagasse is the fibrous plant by-product remaining after removing the sucrose, water, and other extraneous material impurities (e.g. sediment) from the sugarcane brought to the mill. Bagasse, on a dry weight basis, is composed of $40-50 \%$ cellulose, $30-35 \%$ hemicellulose, $20-30 \%$ lignin, and a small percentage of other materials (Cardona et al., 2010; A. R. F. Drummond \& I. W. Drummond, 1996; Martin et al., 2007; Pandey et al., 2000; Sales \& Lima, 2010;). Sugarcane bagasse has been used for paper and fiber board production (Amin, 2011; Xin et al., 2002), cattle feed (Nigam, 1990; Pandey et al., 2000), potting media (Jhurree-Dussoruth et al., 2011; Trochoulias et al., 1990), a mulch for crop production (Webber et al., 2017a), a source for value added products (i.e. pigments, enzymes, amino acids, and drugs) (Pandey et al., 2000), and energy production (thermal conversion and ethanol) (Badger, 2002; Kilicaslan et al., 1999; Martin et al., 2007; Peng et al., 2009; Sun \& Cheng, 2002). 
Louisiana sugarcane mills burn sugarcane bagasse to generate steam power to run equipment within the mill and/or as a boiler fuel for the clarification, evaporation, and crystallization processes. Although the composition of ash produced is dependent on the source of the sugarcane, bagasse ash content is predominately (60-81\%) silica dioxide $\left(\mathrm{SiO}_{2}\right)$ and is low in essential plant nutrients (Payá et al., 2002; Zandersons et al., 1999). Research investigating the use of sugarcane bagasse ash as an amendment to soilless greenhouse growing media determined that the amended media functioned well in many respects for the seedling production of squash, cantaloupe, bean (Phaseolus vulgaris L.), and Chinese kale (Brassica alboglabra). However, Webber et al. 2016; $2017 \mathrm{~b}$ reported that high ratios of bagasse ash $(100 \%)$ increased bulk density $\left(0.12\right.$ to $\left.71 \mathrm{~g} \mathrm{~cm}^{-3}\right)$, resulting in a decrease in the physical growing media properties.

Even after Louisiana sugar mills use $80 \%$ to $90 \%$ of the bagasse for fuel production (Hass \& Lima, 2017; Pandey et al., 2000) 350,000 to $700,000 \mathrm{Mg}$ of bagasse accumulates annually. The conversion of the excess bagasse into biochar is an excellent option to reduce excess material and develop additional income streams. Biochar is the result of incomplete carbonization of organic material under limited oxygen (pyrolysis). Substantial research has been conducted concerning the impact of biochars and "slash and burn" practices on mineral soils with a much smaller quantity directed towards biochars as an amendment to soilless growing media (Barrett et al., 2016; Vaughn et al., 2013). In a research review of environmentally sustainable amendments for soilless growing media, twenty seven different organic materials were listed, including four amendments related to sugarcane waste (Barrett et al., 2016). The sugarcane waste materials included as amendments for soilless growing media were filtercake compost (Stoffella et al., 1996), sugarcane trash/sewage sludge compost (Jayasinghe et al., 2010), sugarcane bagasse ash (Webber et al., 2016), and sugarcane bagasse/manure vermicompost (Khomami \& Moharam, 2013). The three primary criteria for selecting amendments used in soilless growing media are performance, economics, and the increasing emphasis on the environmental impact (Barrett et al., 2016). The primary environmental concern is the identification of suitable alternatives to replace peat in soilless growing media due to several negative environmental impacts of peat harvesting (Alexander et al., 2008; Schmilewski, 2014). Vaughn et al. (2013) investigated the use of biochars from pelletized wood and wheat straw as a replacement ( $5 \%$ to $15 \%)$ for peat in soilless growing media and determined that both biochars would be suitable replacements for peat at $5 \%$ to $15 \%$ rates.

The reported advantages of adding biochars to soils and soilless growing media include a greater ability to retain plant nutrients by reducing nutrient leaching, the addition of nutrients to the soil system, and decreasing the existing bulk densities, which increases aeration and root penetration (Laird, 2008; Vaughn et al., 2013; White et al., 2015). In contrast to sugarcane bagasse ash, adding biochar to a soilless growing media should provide a more ideal physical environment (Laird, 2008; Webber et al., 2016, 2017b). Guo et al. (2018) reported that as PB was combined with soilless growing media from 0 to $100 \%$ biochar in $20 \%$ increments, pore space and bulk densities increased from $21.5 \%$ to $35.7 \%$ volume, and 0.10 to $0.18 \mathrm{~g} \mathrm{~cm}^{-3}$, respectively. Gu et al. (2018) documented that when 5 to $30 \%$ pine biochar was added to a commercial soilless growing media, the production of globe amaranth (Gomphrena globosa L.) var. 'Fireworks' was not adversely affected, although $30 \%$ pine biochar was the highest level investigated. Although in general, biochars have many characteristics in common, the plant material source and the preparation methods employed can greatly influence the properties and effectiveness when used as an amendment in soilless growing media (Vaughn et al., 2013). Greenhouse research was conducted to determine the impact of sugarcane bagasse biochar and pine biochar as an amendment to soilless planting media for the production of green bean (Phaseolus vulgaris L.) seedlings.

\section{Material and Methods}

\subsection{Experimental Design}

The SBB used in the greenhouse experiments was produced and provided by American Biocarbon LLC (White Castle, LA) using proprietary methods. American Biocarbon's torrefaction unit was used to convert the bagasse from the adjacent sugarcane mill (Cora Texas Manufacturing Co., White Castle, LA) into biochar at approximately $340^{\circ} \mathrm{C}$. The SBB was produced from sugarcane harvested in 2015 and transported in large tote bags to the USDA, ARS, Sugarcane Research Unit (Houma, LA) and stored inside until used. Cora Texas sugar mill is one of 11 sugarcane mills that together processed approximately 163,000 ha and 11.7 million $\mathrm{Mg}$ of Louisiana sugarcane in 2016 (American Sugar Cane League, 2017). The PB used in this experiment was produced by Proton Power Inc. (Lenouir City, TN, USA) and provided by Texas A\&M AgriLife Extension (College Station, TX, USA) and is the byproduct of the fast pyrolysis of pinewood at $450{ }^{\circ} \mathrm{C}$ (Gu et al., 2013; Guo et al., 2018; Ingram et al., 2008).

The SBB and PB were combined each by volume with a commercial growing media (Sunshine, Natural and Organic Professional Growing Mix, Sun Gro Horticulture Canada Ltd, Seba Beach, Canada) into five 
combinations [0\%:100\%, 25\%:75\%, 50\%:50\%, 75\%:25\%, and 100\%:0\%, biochars (SBB or PB) and commercial growing media, respectively] which served as experimental treatments. Each of the soilless media treatments were thoroughly mixed prior to placing the mixtures in Speedling ${ }^{\mathcal{O}}$ (Speedling Inc., Ruskin, FL) trays (128 cells, 67.6 $\mathrm{cm} \times 34.6 \mathrm{~cm}$ trays, cells: $3.1 \mathrm{~cm}$ square $\times 6.35 \mathrm{~cm}$ deep). The mixtures were moistened to facilitate the complete and consistent filling of each of the Speedling trays. The Speedling trays were then planted with green bean var. 'Bowie' (Harris Seed Co., 355 Paul Road Rochester, NY 14624).

The greenhouse experiments (USDA, ARS, Sugarcane Research Unit, Houma, LA) were repeated twice in the spring of 2017 and were RCBD. The first bean experiment was planted on March 28, 2017 and harvested 21 days after planting (DAP), April 18, 2017. The second experiment was planted on April 6, 2017 and harvested 21 DAP (April 27, 2017). Each experiment included the 2 types of biochar (SBB and PB) and five soilless media mixtures (0\%:100\%, 25\%:75\%, 50\%:50\%, 75\%:25\%, and 100\%:0\%, biochar and growing media, respectively) and four replications/experiment.

\subsection{Biochar Laboratory Analysis}

Proximate analyses for all samples were performed in triplicate by following the American Society for Testing and Materials (ASTM) method D5142-09 using a thermo-gravimetric analyzer (TGA701, LECO, St. Joseph, MI). Moisture was determined as the weight loss after heating the sample under $\mathrm{N}_{2}$ atmosphere in open crucibles to $107{ }^{\circ} \mathrm{C}$ to stable sample weight. Volatile matter was determined as weight loss after heating sample under $\mathrm{N}_{2}$ atmosphere in covered crucibles to $950{ }^{\circ} \mathrm{C}$ for $7 \mathrm{~min}$. Ash was calculated from remaining mass after heating sample under $\mathrm{O}_{2}$ atmosphere in open crucibles to $750^{\circ} \mathrm{C}$ and holding to stable weight. Fixed carbon was calculated by difference.

Surface area measurements (duplicate samples) were obtained from nitrogen adsorption isotherms at $77^{\circ} \mathrm{K}$ using a Nova 2200e Surface Area Analyzer (Quantachrome Corp., Boynton Beach, FL). Specific surface areas (BET, Brunner-Emmett-Teller) were taken from adsorption isotherms using the BET equation. The micro pore size distributions were calculated using t-plots derived from the Nova 2200 software. A Thermo Orion $\mathrm{pH}$ meter (Beverly, MA) was used to measure $\mathrm{pH}$, where $1.0 \mathrm{~g}$ of sample was placed in $100 \mathrm{~mL}$ of deionized water, covered with Parafilm, and allowed to equilibrate by stirring at $300 \mathrm{rpm}$ for $48 \mathrm{~h}$ (duplicate samples).

\subsection{Physical Analysis of Biochar Amendment Combinations}

Each soilless media mixture was analyzed for bulk density $\left(\mathrm{g} \mathrm{cm}^{-3}\right)$, porosity $(\%)$, water saturation (\%), and water at field capacity (\%). Each physical test on the soil media mixtures was repeated four times. The measuring chamber was a cylinder with a $40 \mathrm{~mm}$ inner diameter and an interior height of $64.5 \mathrm{~mm}$ with a measured volume of $81 \mathrm{~cm}^{3}$.

\subsection{Plant Growth and Analysis}

Five bean seedlings from the center of each tray were randomly harvested 21 DAP. Each seedling was divided into above and below ground plant portions. Plant height was determined by measuring the distance from the media surface to the apical meristem. The upper portion of the plant was further divided into leaves and stalks. The plant roots were weighted after removing all planting media from root system. Fresh weight of the leaves, stalks, and roots was recorded. The plant portions were then oven-dried for 2 days at $60{ }^{\circ} \mathrm{C}$ and then subsequently reweighed to determine dry weights. Plant establishment was determined at harvest by calculating the percentage of Speedling ${ }^{\circledR}$ planting cells containing viable seedlings. All data were subjected to ANOVA and mean separation using LSD with $\mathrm{P}=0.05$ (SAS Inc., SAS, Ver. 9.0, Cary, NC).

\section{Results and Discussion}

\subsection{Laboratory Analysis of Biochars}

The laboratory analysis determined that the PB moisture content (MC), fixed carbon (FixC), higher heating value (HHV), lower heating value, and $\mathrm{pH}$ were greater than the SBB by $1.7 \%$ (MC), $44 \%$ (FixC), $10.7 \mathrm{MJ} \mathrm{kg}^{-1}$ (HHV), $9.5 \mathrm{MJ} \mathrm{kg}^{-1}$ (LHV), and $2.25 \mathrm{pH}$, respectively (Table 1). The SBB also had 31.7\% greater volatile matter (VOL) and $12.4 \%$ greater ash (ash) than PB (Table 1). An increase in ash content typically will increase the biochar's bulk density and potential nutrient availability for seedling production (Webber et al., 2017b). The greater fixed carbon percentage increases the energy value (HHV and LHV) of the PB compared to the SBB, and may influence the potential income streams for the two biochars (Table 1). 
Table 1. Laboratory analysis of sugarcane bagasse biochar (SBB) and pine biochar (PB) for moisture content (MC), volatile matter (VOL), fixed carbon (FixC), ash (ASH), higher heating value (HHV), lower heating value (LHV), and $\mathrm{pH}$

\begin{tabular}{llllllll}
\hline Biochar & MC & VOL & FixC & Ash & HHV & LHV & pH \\
\hline & $\%$ & $\%$ & $\%$ & $\%$ & $\mathrm{MJ} \mathrm{kg}^{-1}$ & $\mathrm{MJ} \mathrm{kg}^{-1}$ & \\
$\underline{\mathrm{SBB}}^{\mathrm{Z}}$ & $6.9 \pm 0.41$ & $44.0 \pm 1.00$ & $38.8 \pm 0.43$ & $17.2 \pm 1.13$ & $20.5 \pm 0.24$ & $19.0 \pm 0.23$ & $5.80 \pm 0.05$ \\
$\underline{\mathrm{PB}}^{\mathrm{Y}}$ & $8.55 \pm 0.33$ & $12.3 \pm 0.23$ & $82.9 \pm 0.83$ & $4.79 \pm 0.62$ & $31.2 \pm 0.27$ & $28.5 \pm 0.26$ & $8.05 \pm 0.01$ \\
\hline
\end{tabular}

Note. ${ }^{\mathrm{Z}} \mathrm{SBB}=$ Sugarcane Bagasse Biochar produced by American Biocarbon LLC. ${ }^{\mathrm{P} B}$ P $=$ Pine Biochar. Volatiles, fixed carbon, and ash in percent dry basis.

The particle size distribution for the two biochar are in stark contrast to each other with the laser analysis revealing that the $\mathrm{PB}$ particle median, mean, geometric mean, and mode were much greater than those of the SBB (Table 2). The PB particle size distribution were 3.8x (median), 4.3x (mean), 2.9x (geometric mean), and 5.1x (mode) greater than the SBB sizes (Table 2). And, unlike the unimodal particle size distribution that produced a single peak at near $110 \mu \mathrm{m}$ for SBB, the PB particle distribution produced a bimodal curve with the first and smaller peak at $10 \mu \mathrm{m}$ and the second and larger peak at $1000 \mu \mathrm{m}$.

Table 2. Laser scattering particle size distribution analysis (LA-950) of sugarcane bagasse biochar (SBB) and pine biochar (PB) used as amendments to the greenhouse soilless growing media

\begin{tabular}{lllll}
\hline Biochar & Median & Mean & Geometric Mean & Mode \\
\hline & $\mu \mathrm{m}$ & $\mu \mathrm{m}$ & $\mu \mathrm{m}$ & $\mu \mathrm{m}$ \\
$\underline{\mathrm{SBB}}^{\mathrm{Z}}$ & 142.03 & 166.53 & 111.19 & 213.84 \\
$\underline{\mathrm{PB}}^{\mathrm{Y}}$ & 537.54 & 707.61 & 326.16 & 1091.87 \\
\hline
\end{tabular}

Note. ${ }^{\mathrm{Z}} \mathrm{SBB}=$ Sugarcane Bagasse Biochar produced by American Biocarbon LLC. ${ }^{\mathrm{Y}} \mathrm{PB}=$ Pine Biochar produced by Proton Power, Inc.

\subsection{Physical Analysis of Amendment Concentrations: Bulk Density and Porosity}

The bulk densities of the media mixtures increased from $0.11 \mathrm{~g} \mathrm{~cm}^{-3}$ (the commercial medium: $0 \% \mathrm{SSB}$ and $0 \%$ PB) to $0.14 \mathrm{~g} \mathrm{~cm}^{-3}$ for the $25 \% \mathrm{SBB}$ and $0.17 \mathrm{~g} \mathrm{~cm}^{-3}$ for the $100 \%$ PB (Table 3). The bulk densities for SBB decreased from its high at $25 \%$ biochar down to $0.11 \mathrm{~g} \mathrm{~cm}^{-3}$ for the $100 \% \mathrm{SBB}$, while the bulk densities for PB media increased as the percentage of PB increased (Table 3). These results are in contrast to similar research using the same mixture combinations with sugarcane bagasse ash instead of sugarcane biochar (Webber et al., 2017b). The bulk densities remained in an ideal range when the biochars were added, unlike earlier research where the addition of sugarcane bagasse ash increased bulk densities from 0.12 to $0.71 \mathrm{~g} \mathrm{~cm}^{-3}$ (Webber et al., 2017b). In contrast to Vaughn et al. (2013) who used biochar wood $\left(0.62 \mathrm{~g} \mathrm{~cm}^{-3}\right)$ and straw pellets $\left(0.24 \mathrm{~g} \mathrm{~cm}^{-3}\right)$ as a suitable replacement for peat at substitution rates of 5 to $15 \%$, the SBB and PB bulk densities for SBB and PB were suitable at all percentages (Table 3). The SBB bulk densities were not different from the commercial soilless growing media used in the research except for $25 \% \mathrm{SB}$ media $\left(0.14 \mathrm{~g} \mathrm{~cm}^{-3}\right)$ and all SBB and PB combinations were comparable to the bulk density of peat, $0.16 \mathrm{~g} \mathrm{~cm}^{-3}$, measured by Vaughn et al. (2013). The lower bulk density values of the SBB maintained bulk densities in a suitable range as the biochar content increased from 0 to $100 \%$ of the growing media (Table 3), while the slightly greater PB bulk density also kept the media bulk densities in an acceptable range (Table 3). These results were consistent with Guo et al. (2018) who reported bulk densities from 0.10 to $0.18 \mathrm{~g} \mathrm{~cm}^{-3}$ when pine biochar was added to a soilless growing media for the production of poinsettia (Euphorbia pulcherrima).

As the biochar percentage increased in the SBB media mixtures, the pore space, water saturation, and water at field capacity percentages remained fairly constant, in contrast to the PB media mixtures which peaked at $0 \%$ PB and decreased as the percentage of PB increased (Table 3). The pore space, water saturation, and water field capacity values for all mixture combinations for both biochars were at adequate levels to provide sufficient water availability to young seedlings. This is in contrast to research with sugarcane bagasse ash where the water saturation and water at field capacity decreased significantly as the percentage of ash increased in the greenhouse growing mixtures (Webber et al., 2017b). 
Table 3. Impact of sugarcane biochar and pine-char percentage as an amendment to greenhouse growing media on bulk density $\left(\mathrm{g} \mathrm{cm}^{-3}\right)$, percent total pore space, percent water saturation, and percent water at field capacity

\begin{tabular}{lllll}
\hline Composition $^{\mathrm{Z}}$ & Bulk Density & Pore Space & Water Saturation & Water at Field Capacity \\
\hline$\underline{\mathrm{SBB}}^{\mathrm{Y}}$ & $\mathrm{g} \mathrm{cm}^{-3}$ & $\%$ & $\%$ & $\%$ \\
$0 \%$ & & & \\
$25 \%$ & $0.11 \mathrm{e}^{\mathrm{W}}$ & $71.18 \mathrm{~b}$ & $86.49 \mathrm{a}$ & $84.35 \mathrm{a}$ \\
$50 \%$ & $0.14 \mathrm{~cd}$ & $76.79 \mathrm{a}$ & $84.92 \mathrm{a}$ & $79.64 \mathrm{~b}$ \\
$75 \%$ & $0.13 \mathrm{de}$ & $71.47 \mathrm{~b}$ & $84.96 \mathrm{a}$ & $83.48 \mathrm{a}$ \\
$100 \%$ & $0.12 \mathrm{e}$ & $73.13 \mathrm{ab}$ & $86.28 \mathrm{a}$ & $84.34 \mathrm{a}$ \\
$\underline{\mathrm{PB}}^{\mathrm{X}}$ & $0.11 \mathrm{e}$ & $73.80 \mathrm{ab}$ & $86.92 \mathrm{a}$ & $85.28 \mathrm{a}$ \\
$0 \%$ & & & \\
$25 \%$ & $0.11 \mathrm{e}$ & $71.18 \mathrm{~b}$ & $86.49 \mathrm{a}$ & $84.35 \mathrm{a}$ \\
$50 \%$ & $0.13 \mathrm{~cd}$ & $57.09 \mathrm{c}$ & $80.98 \mathrm{~b}$ & $77.16 \mathrm{c}$ \\
$75 \%$ & $0.15 \mathrm{bc}$ & $60.91 \mathrm{c}$ & $80.59 \mathrm{~b}$ & $76.10 \mathrm{c}$ \\
$100 \%$ & $0.15 \mathrm{ab}$ & $60.57 \mathrm{c}$ & $79.60 \mathrm{~b}$ & $72.98 \mathrm{~d}$ \\
\hline
\end{tabular}

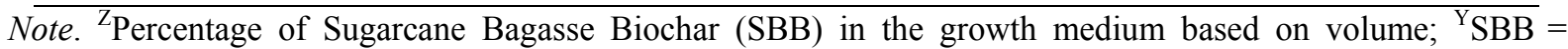
Sugarcane Bagasse Biochar produced by American Biocarbon LLC. ${ }^{\mathrm{X}} \mathrm{PB}=$ Pine Biochar provided by Texas A\&M and produced by Proton Power, Inc. ${ }^{\mathrm{W}}$ Means in a column followed by the same lower case letter are not significantly different at $\mathrm{P}=0.05$, ANOVA.

\subsection{Seedling Analysis}

\subsubsection{Bean Seedling Fresh and Dry Weights}

There were no significant experiment $\times$ treatment interactions for the bean seedling fresh and dry weights (Table 4), therefore the bean seedling data will be discussed across experiments (Tables 5 and 6).

Table 4. Analysis of variance (ANOVA) for bean fresh and dry weights for source factors experiments, treatments, and experiment $\times$ treatment

\begin{tabular}{|c|c|c|c|c|c|}
\hline \multirow{2}{*}{ Source } & \multicolumn{5}{|c|}{ Bean Seedling Fresh Weights } \\
\hline & Stalk & Leaves & Tops & Roots & Total \\
\hline & $\operatorname{Pr}>F$ & $\operatorname{Pr}>F$ & $\operatorname{Pr}>F$ & $\operatorname{Pr}>F$ & $\operatorname{Pr}>F$ \\
\hline Experiment & $<.0001$ & $<.0001$ & $<.0001$ & $0.6521^{\mathrm{Z}}$ & $<.0001$ \\
\hline Treatment & $0.67859^{\mathrm{Z}}$ & $0.0637^{Z}$ & $0.1787^{Z}$ & 0.0065 & $0.0978^{Z}$ \\
\hline Experiment $\times$ Treatment & $0.2171^{\mathrm{Z}}$ & $0.2256^{\mathrm{Z}}$ & $0.2576^{\mathrm{Z}}$ & $0.1642^{Z}$ & $0.2959^{Z}$ \\
\hline \multirow{3}{*}{ Source } & \multicolumn{5}{|c|}{ Bean Seedling Dry Weights } \\
\hline & Stalk & Leaves & Tops & Roots & Total \\
\hline & $\operatorname{Pr}>F$ & $\operatorname{Pr}>F$ & $\operatorname{Pr}>F$ & $\operatorname{Pr}>F$ & $\operatorname{Pr}>F$ \\
\hline Experiment & 0.0035 & $<.0001$ & $<.0001$ & 0.0201 & $<.0001$ \\
\hline Treatment & $0.6396^{\mathrm{Z}}$ & $0.0705^{\mathrm{Z}}$ & $0.2008^{\mathrm{Z}}$ & $0.9973^{Z}$ & $0.3940^{Z}$ \\
\hline Experiment $\times$ Treatment & $0.1509^{Z}$ & $0.1949^{Z}$ & $0.1869^{Z}$ & $0.1312^{Z}$ & $0.2341^{Z}$ \\
\hline
\end{tabular}

Note. ${ }^{\mathrm{Z}}$ Not Significantly Different at $\mathrm{P}=0.05$, PROC ANOVA.

Except for the $100 \%$ PB media, all the SBB and PB planting mixtures performed well compared to the commercial greenhouse growing media $(0 \% \mathrm{SBB}$ and $0 \% \mathrm{~PB})$ for bean seedling development in respect to the fresh and dry weights (Tables 5 and 6). Earlier research (Guo et al., 2018) reported a similar pattern when PB was added to a commercial soilless growing media for the production of poinsettia in a greenhouse production setting. Poinsettia growth and development was not adversely affected by $80 \%$ PB content, but $100 \%$ PB was not recommended. The $100 \% \mathrm{~PB}$ exception was seen with the weight of the dry bean leaves, where the average experimental dry weighs were significantly less for the $100 \% \mathrm{~PB}(1.42 \mathrm{~g})$ compared to the standard greenhouse media (1.68 g) (Table 6). Same was true for the tops dry weight with $2.03 \mathrm{~g}$ with $100 \% \mathrm{~PB}$ versus $2.39 \mathrm{~g}$ for the 
standard greenhouse media (Table 6). The $100 \%$ SBB actually produced more roots on the fresh weight basis $(3.85 \mathrm{~g})$ than the commercial greenhouse mixture $(2.74 \mathrm{~g})$ and all other mixture combinations (Table 5). The $100 \% \mathrm{SBB}$ also produced greater total seedling fresh weight $(24.83 \mathrm{~g})$ than all of the media mixtures containing PB $(25 \%, 50 \%, 75 \%$, and $100 \%$ PB) and significantly more fresh leaves $(15.19 \mathrm{~g})$ than the $100 \%$ PB mixture $(12.78 \mathrm{~g})$ (Table 5). The 50\% SBB produced greater leaf $(16.25 \mathrm{~g})$ and top seedling $(22 \mathrm{~g})$ weights than all of the mixtures containing PB $(25 \%, 50 \%, 75 \%$, and $100 \%$ PB) (Table 5).

In the same manner, select bean seedling dry weights of the SBB mixtures were often greater than those of certain PB mixtures (Table 6). For example, SBB 50\% leaf dry weigh production $(1.80 \mathrm{~g})$ was greater than any growing media containing PB $(25 \%, 50 \%, 75 \%$, and $100 \%)$ and the $100 \%$ SBB dry leaf weight $(1.71 \mathrm{~g})$ was greater than the corresponding $100 \%$ PB mixture $(1.42 \mathrm{~g})$. The bean seedling tops dry weights for $50 \% \mathrm{SBB}$ $(2.51 \mathrm{~g})$ were greater than $25 \%$ and $100 \%$ PB mixtures, 2.14 and $1.42 \mathrm{~g}$, respectively (Table 6). The $100 \%$ SBB also had a greater seedling top weight $(2.42 \mathrm{~g})$ than the corresponding $100 \%$ PB mixture $(2.03 \mathrm{~g})$ (Table 6). Lastly, largest seedling dry weight $(2.99 \mathrm{~g})$ was observed for the $50 \%$ SBB mixture while the lowest was obtained with $100 \%$ PB (at $2.48 \mathrm{~g}$ ) (Table 6).

Table 5. Impact of sugarcane bagasse biochar and pine biochar soilless media percentages on bean seedling stalk, leaves, tops, and total fresh weights $(\mathrm{g})$ averaged across two experiments, four replications per experiment, and five seedlings per replication

\begin{tabular}{|c|c|c|c|c|c|c|c|c|c|c|}
\hline \multirow{2}{*}{ Biochar $^{Z}$} & \multicolumn{10}{|c|}{ Bean Seedling Fresh Weights $(\mathrm{g})$} \\
\hline & \multicolumn{2}{|l|}{ Stalk } & \multicolumn{2}{|c|}{ Leaves } & \multicolumn{2}{|l|}{ Tops } & \multicolumn{2}{|c|}{ Roots } & \multicolumn{2}{|l|}{ Total } \\
\hline $0 \%$ & 5.65 & $\mathrm{a}^{\mathrm{W}}$ & 14.88 & $a b c$ & 20.53 & $\mathrm{ab}$ & 2.74 & $\mathrm{~b}$ & 23.26 & $a b c$ \\
\hline $25 \%$ & 5.16 & $\mathrm{a}$ & 14.24 & $a b c$ & 19.40 & $a b$ & 2.33 & $\mathrm{~b}$ & 21.74 & $a b c$ \\
\hline $50 \%$ & 5.74 & $\mathrm{a}$ & 16.27 & $\mathrm{a}$ & 22.00 & $\mathrm{a}$ & 2.69 & $\mathrm{~b}$ & 24.69 & $a b$ \\
\hline $75 \%$ & 5.58 & $\mathrm{a}$ & 14.49 & $a b c$ & 20.07 & $\mathrm{ab}$ & 2.56 & $\mathrm{~b}$ & 22.63 & $a b c$ \\
\hline $100 \%$ & 5.79 & $\mathrm{a}$ & 15.19 & $a b$ & 20.98 & $\mathrm{ab}$ & 3.85 & a & 24.83 & $\mathrm{a}$ \\
\hline \multicolumn{11}{|l|}{$\underline{\mathrm{PB}}^{\mathrm{X}^{--}}$} \\
\hline $0 \%$ & 5.65 & $\mathrm{a}$ & 14.88 & $a b c$ & 20.53 & $a b$ & 2.74 & $\mathrm{~b}$ & 23.26 & $a b c$ \\
\hline $25 \%$ & 5.27 & $\mathrm{a}$ & 13.13 & $\mathrm{bc}$ & 18.40 & $\mathrm{~b}$ & 2.81 & $\mathrm{~b}$ & 21.21 & $\mathrm{bc}$ \\
\hline $50 \%$ & 5.35 & $\mathrm{a}$ & 13.27 & $\mathrm{bc}$ & 18.61 & $\mathrm{~b}$ & 2.53 & $\mathrm{~b}$ & 21.14 & $\mathrm{bc}$ \\
\hline $75 \%$ & 5.40 & $\mathrm{a}$ & 12.88 & $\mathrm{bc}$ & 18.28 & $\mathrm{~b}$ & 2.58 & $\mathrm{~b}$ & 20.85 & $\mathrm{c}$ \\
\hline $100 \%$ & 5.04 & $\mathrm{a}$ & 12.78 & $\mathrm{c}$ & 17.82 & $\mathrm{~b}$ & 2.29 & $\mathrm{~b}$ & 20.11 & $\mathrm{c}$ \\
\hline
\end{tabular}

Note. ${ }^{\mathrm{Y} P e r c e n t a g e}$ of sugarcane biochar in the growth medium based on volume; ${ }^{\mathrm{Y}} \mathrm{SBB}=$ Sugarcane Bagasse Biochar produced by American Biocarbon LLC. ${ }^{\mathrm{X}} \mathrm{PB}=$ Pine Biochar provided by Texas A\&M. ${ }^{\mathrm{W}}$ Means in a column followed by the same lower case letter are not significantly different at $\mathrm{P}=0.05$, ANOVA. 
Table 6. Impact of sugarcane bagasse biochar and pine biochar soilless media percentages on bean seedling stalk, leaves, tops, and total dry weights $(\mathrm{g})$ averaged across two experiments, four replications per experiment, and five seedlings per replication

\begin{tabular}{|c|c|c|c|c|c|c|c|c|c|c|}
\hline \multirow{3}{*}{$\begin{array}{l}\text { Biochar }^{\mathrm{Z}} \\
\underline{\mathrm{SBB}}^{\mathrm{Y}}\end{array}$} & \multicolumn{10}{|c|}{ Bean Seedling Dry Weights (g) } \\
\hline & \multicolumn{2}{|l|}{ Stalk } & \multicolumn{2}{|c|}{ Leaves } & \multicolumn{2}{|c|}{ Tops } & \multicolumn{2}{|c|}{ Roots } & \multicolumn{2}{|l|}{ Total } \\
\hline & & & & & & & & & & \\
\hline$\overline{0 \%}$ & 0.72 & $a^{\mathrm{W}}$ & 1.68 & $a b$ & 2.39 & $a b$ & 0.45 & a & 2.84 & $a b$ \\
\hline $25 \%$ & 0.61 & $\mathrm{a}$ & 1.59 & abc & 2.19 & $a b c$ & 0.45 & a & 2.64 & $a b$ \\
\hline $50 \%$ & 0.71 & a & 1.80 & a & 2.51 & a & 0.48 & a & 2.99 & $\mathrm{a}$ \\
\hline $75 \%$ & 0.65 & $\mathrm{a}$ & 1.59 & abc & 2.24 & abc & 0.44 & a & 2.68 & $a b$ \\
\hline $100 \%$ & 0.70 & a & 1.71 & $\mathrm{ab}$ & 2.42 & $\mathrm{ab}$ & 0.48 & a & 2.89 & $a b$ \\
\hline \multicolumn{11}{|l|}{$\mathrm{PB}^{\mathrm{X}^{-}}$} \\
\hline $0 \%$ & 0.72 & $\mathrm{a}$ & 1.68 & $\mathrm{ab}$ & 2.39 & $\mathrm{ab}$ & 0.45 & $\mathrm{a}$ & 2.84 & $a b$ \\
\hline $25 \%$ & 0.66 & $\mathrm{a}$ & 1.48 & $\mathrm{bc}$ & 2.14 & $\mathrm{bc}$ & 0.44 & $\mathrm{a}$ & 2.58 & $a b$ \\
\hline $50 \%$ & 0.69 & $\mathrm{a}$ & 1.54 & $\mathrm{bc}$ & 2.23 & $a b c$ & 0.47 & $\mathrm{a}$ & 2.70 & $a b$ \\
\hline $75 \%$ & 0.67 & $\mathrm{a}$ & 1.52 & $\mathrm{bc}$ & 2.20 & $a b c$ & 0.46 & $\mathrm{a}$ & 2.66 & $a b$ \\
\hline $100 \%$ & 0.62 & $\mathrm{a}$ & 1.42 & $\mathrm{c}$ & 2.03 & $\mathrm{c}$ & 0.44 & $\mathrm{a}$ & 2.48 & $\mathrm{~b}$ \\
\hline
\end{tabular}

Note. ${ }^{\mathrm{Z}}$ Percentage of sugarcane biochar in the growth medium based on volume; ${ }^{\mathrm{Y}} \mathrm{SBB}=$ Sugarcane Bagasse Biochar produced by American Biocarbon LLC. ${ }^{\mathrm{X}} \mathrm{PB}=$ Pine Biochar provided by Texas A\&M and produced by Proton Power, Inc. ${ }^{\mathrm{W}}$ Means in a column followed by the same lower case letter are not significantly different at $\mathrm{P}=$ 0.05 , ANOVA.

\subsubsection{Bean Seedling Height, Establishment, Deformed, and Marketable}

There were no significant experiment $\times$ treatment interactions $(P=0.05)$ for the bean seedling height or percent marketable bean seedlings (Table 7), therefore this data will be discussed across experiments (Table 8), while the percentage seedling establishment and deformed will be discussed by experiments (Table 8).

Table 7. Analysis of variance (ANOVA) for bean plant height, percent plant establishment, percent deformed plants, and percent marketable plants for source factors experiments, treatments, and experiment $\times$ treatment

\begin{tabular}{lllll}
\hline Source & Height & Establishment & Deformed & Marketable \\
\hline & $\operatorname{Pr}>\mathrm{F}$ & $\operatorname{Pr}>\mathrm{F}$ & $\operatorname{Pr}>\mathrm{F}$ & $\operatorname{Pr}>\mathrm{F}$ \\
Experiment & $<.0001$ & $<.0001$ & $<.0001$ & $<.0001$ \\
Treatment & $0.6966^{\mathrm{Z}}$ & 0.0068 & $<.0001$ & $<.0001$ \\
Experiment $\times$ Treatment & $0.1717^{\mathrm{Z}}$ & 0.0346 & 0.0483 & 0.0658 \\
\hline
\end{tabular}

Note. ${ }^{\mathrm{Z}}$ Not Significantly Different at $\mathrm{P}=0.05$, PROC ANOVA.

Sugarcane bagasse biochar plant media percentages did not influence plant height when averaged across the 2 experiments (Table 8). Bean seedling establishment was excellent for 'Experiment 1', ranging from 92.6\% $(100 \% \mathrm{~PB})$ to $99.6 \%(75 \% \mathrm{SBB} \& 25 \% \mathrm{~PB})$ with only a significant decrease at the $100 \% \mathrm{~PB}(92.6 \%)$ treatment (Table 8). In 'Experiment 2' bean seedling establishment was typically less than Experiment 1, ranging from $91.8 \%(50 \% \mathrm{~PB})$ to $97.7 \%(25 \% \mathrm{~PB})$ with significantly less plants at 25\% SBB $(90.2 \%)$ and $\mathrm{PB} 50 \%(91.8 \%)$ (Table 8). In seedling deformity in Experiment 1 was fairly low $(0.39 \%$ to $3.5 \%)$ for all planting media combination except for $100 \%$ PB, which produced an increase in deformed seedlings (8.6\%) (Table 8). Seedling deformity was much greater in all planting media combinations in Experiment 2 compared to Experiment 1, ranging from $6.3 \%(75 \% \mathrm{~PB})$ to $17.6 \%(100 \% \mathrm{~PB})$. Yet, it must be noted that in both Experiments 1 and 2 it was only the $100 \%$ PB media that produced significantly greater deformed seedlings than the commercial greenhouse media ( $0 \%$ SBB and PB $0 \%)$ and in several treatments $(100 \% \mathrm{SBB}, 25 \% \mathrm{~PB}, 50 \% \mathrm{~PB}$ and $75 \% \mathrm{~PB})$ the percent of seedling deformity was actually less than the commercial greenhouse media ( $0 \%$ SBB and PB $0 \%)$ (Table 8$)$. The seedling establishment and deformity data were used to determine the percentage of seedlings suitable for marketing. The PB media combinations exhibited the greatest differences for percent marketable bean seedlings, $80.9 \%(100 \% \mathrm{~PB})$ to $93.6 \%(25 \% \mathrm{~PB})$, compared to the SBB range of $86.1 \%(25 \% \mathrm{SBB})$ to $92.6 \%(100 \% \mathrm{SBB})$ (Table 8$)$. The $100 \%$ PB ( $80.9 \%$ marketable seedlings) was the only mixture combination averaged across both experiments that reduced marketable seedlings compared to the standard greenhouse media mixture $(90.4 \%$ 
marketable seedlings) (Table 8). Based on seedling deformity and the resulting marketable seedling data, the authors suggest that the producer do not use a 100\% PB growing media for the production of bean seedlings. The $100 \%$ PB produced the lowest seedling establishment (Experiment 1), the greatest deformities (Experiments 1 and 2), and the lowest percentage of marketable seedlings (averaged across Experiments 1 and 2) (Table 8). Perhaps the establishment and deformity issues were related to the larger particle size distribution of the PB compared to the SBB or perhaps the PB is naturally more abrasive to plant tissues than the SBB. When observing the deformed bean seedlings, the seedling's epicotyl and cotyledons were scared as if the biochars abrasiveness was damaging the seedlings as the seedlings were emerging and establishment.

Table 8. Impact of sugarcane bagasse biochar and pine biochar on bean seedling height $(\mathrm{cm})$, seedling establishment (\%), deformed seedlings (\%), and marketable seedlings

\begin{tabular}{|c|c|c|c|c|c|c|c|c|c|c|c|c|}
\hline \multirow{2}{*}{ Biochar $^{Z}$} & \multirow{2}{*}{\multicolumn{2}{|c|}{$\begin{array}{l}\text { Seedling } \\
\text { Height }\end{array}$}} & \multicolumn{4}{|c|}{ Seedling Establishment } & \multicolumn{4}{|c|}{ Deformed Seedlings } & \multirow{2}{*}{\multicolumn{2}{|c|}{$\begin{array}{l}\text { Marketable } \\
\text { Seedlings }\end{array}$}} \\
\hline & & & \multicolumn{2}{|c|}{ Expt. \#1 } & \multicolumn{2}{|c|}{ Expt. \#2 } & \multicolumn{2}{|c|}{ Expt. \#1 } & \multicolumn{2}{|c|}{ Expt. \#2 } & & \\
\hline$\underline{\mathrm{SBB}}^{\mathrm{Y}}$ & $\mathrm{cm}$ & & $\%$ & & $\%$ & & $\%$ & & $\%$ & & $\%$ & \\
\hline $0 \%$ & 14.33 & $\mathrm{a}^{\mathrm{W}}$ & 98.05 & $\mathrm{a}$ & 96.49 & $\mathrm{ab}$ & 0.78 & $\mathrm{~b}$ & 12.89 & $\mathrm{bc}$ & 90.43 & $\mathrm{ab}$ \\
\hline $25 \%$ & 12.78 & $\mathrm{a}$ & 97.27 & $\mathrm{a}$ & 90.24 & $\mathrm{c}$ & 1.56 & $\mathrm{~b}$ & 13.67 & $\mathrm{~b}$ & 86.13 & $\mathrm{~b}$ \\
\hline $50 \%$ & 13.32 & $\mathrm{a}$ & 96.88 & $\mathrm{a}$ & 92.19 & $\mathrm{bc}$ & 3.52 & $\mathrm{~b}$ & 11.33 & bcd & 87.11 & $b$ \\
\hline $75 \%$ & 13.94 & $\mathrm{a}$ & 99.61 & $\mathrm{a}$ & 95.70 & $a b$ & 1.17 & $\mathrm{~b}$ & 9.38 & $\operatorname{cdf}$ & 92.38 & $\mathrm{a}$ \\
\hline $100 \%$ & 14.50 & $\mathrm{a}$ & 97.66 & $\mathrm{a}$ & 96.49 & $a b$ & 0.39 & $\mathrm{~b}$ & 8.60 & de & 92.58 & $\mathrm{a}$ \\
\hline \multicolumn{13}{|l|}{$\underline{\mathrm{PB}}^{\mathrm{X}^{--}}$} \\
\hline $0 \%$ & 14.33 & a & 98.05 & $\mathrm{a}$ & 96.49 & $a b$ & 0.78 & $\mathrm{~b}$ & 12.89 & $\mathrm{bc}$ & 90.43 & $\mathrm{ab}$ \\
\hline $25 \%$ & 14.31 & $\mathrm{a}$ & 99.61 & $\mathrm{a}$ & 97.66 & $\mathrm{a}$ & 3.13 & $\mathrm{~b}$ & 7.03 & $\mathrm{e}$ & 93.56 & $\mathrm{a}$ \\
\hline $50 \%$ & 13.88 & $\mathrm{a}$ & 98.83 & $\mathrm{a}$ & 91.80 & $\mathrm{bc}$ & 1.56 & $\mathrm{~b}$ & 8.21 & de & 90.43 & $a b$ \\
\hline $75 \%$ & 13.96 & $\mathrm{a}$ & 98.83 & $\mathrm{a}$ & 95.31 & $a b$ & 1.17 & $\mathrm{~b}$ & 6.25 & $\mathrm{e}$ & 92.38 & $\mathrm{a}$ \\
\hline $100 \%$ & 12.35 & $\mathrm{a}$ & 92.58 & $\mathrm{~b}$ & 95.13 & $a b$ & 8.60 & $\mathrm{a}$ & 17.58 & $\mathrm{a}$ & 80.86 & $\mathrm{c}$ \\
\hline
\end{tabular}

Note. ${ }^{\mathrm{P}}$ Percentage of sugarcane biochar in the growth medium based on volume; ${ }^{\mathrm{Y}} \mathrm{SBB}=$ Sugarcane Bagasse Biochar produced by American Biocarbon LLC. ${ }^{\mathrm{X}} \mathrm{PB}=$ Pine Biochar provided by Texas A\&M and produced by Proton Power, Inc. ${ }^{\mathrm{W}}$ Means in a column followed by the same lower case letter are not significantly different at $\mathrm{P}=$ 0.05 , ANOVA.

\section{Conclusions}

When using a biochar as an amendment for growing medium, it is important to evaluate its various physico-chemical properties. Biochars herein utilized were sourced from different plant species (sugarcane vs. pine) and converted to biochars through different processes, resulting in different physical and chemical compositions. Although these differences may not be critical to all biochar uses, the information may be critical in understanding the potential applications of the biochars. The greater fixed carbon percentage increases the energy value (HHV and LHV) of the PB compared to the SBB, and may influence the potential income streams for the two biochars. The particle size distribution for the two biochars are in stark contrast to each other with the PB particle median, mean, geometric mean, and mode being much greater than those of the SBB. These differences in particle size and distribution significantly increased the bulk density and decreased the pore space (\%), water saturation (\%), and water at field capacity (\%) of the PB in contrast to the SBB, although these parameters remain in suitable ranges for soilless growing media. The $100 \%$ SBB was not significantly different in any of these parameters to the standard soilless growing media. As amendments to the soilless greenhouse growing media, the biochars (SBB and PB) functioned very well especially at the 25 and $75 \%$ levels for bean seedling production. The $100 \%$ SBB preform as well as the $100 \%$ commercial soilless growing media and slightly better than the $100 \%$ PB when comparing seedling fresh and dry weights. The $100 \%$ PB is not recommended as a soilless growing media even with the supplemental fertilizer used in these experiments. These results indicate that the volume of a standard soilless greenhouse growing media can be successfully extended by adding $25 \%$ to $75 \%$ of either sugarcane bagasse or pine biochars without reducing bean seedling production quality. Future research is needed to evaluate these biochar sources for seedling production for additional plant species. 


\section{Acknowledgements}

The authors would also like to thank Roddy Hulett, American Biocarbon LLC and the Cora Texas manufacturing sugar mill, White Castle, Louisiana for supplying the biochar for the experiment. The work would have been impossible without the technical support of USDA, Agricultural Research Service technicians Derek Landrum, Christopher Adams, Eric Petrie, Norris Matherne, and Frank Randell.

\section{Trade Names or Commercial Products}

Mention of trade names or commercial products in this publication is solely for the purpose of providing specific information and does not imply recommendation or endorsement by the U.S. Department of Agriculture.

\section{EEO/Non-Discrimination Statement}

The U.S. Department of Agriculture (USDA) prohibits discrimination in all its programs and activities on the basis of race, color, national origin, age, disability, and where applicable, sex, marital status, familial status, parental status, religion, sexual orientation, genetic information, political beliefs, reprisal, or because all or part of an individual's income is derived from any public assistance program. (Not all prohibited bases apply to all programs.) Persons with disabilities who require alternative means for communication of program information (Braille, large print, audiotape, etc.) should contact USDA's TARGET Center at (202) 720-2600 (voice and TDD). To file a complaint of discrimination, write to USDA, Director, Office of Civil Rights, 1400 Independence Avenue, S.W., Washington, D.C. 20250-9410, or call (800) 795-3272 (voice) or (202) 720-6382 (TDD). USDA is an equal opportunity provider and employer.

\section{References}

Alexander, P. D., Bragg, N. C., Meade, R., Padelopoulos, G., \& Watts, O. (2008). Peat in horticulture and conservation: The UK response to a changing world. Mires \& Peat, 3(8), 1-10. Retrieved from $\mathrm{http} / / /$ pixelrauschen.de/wbmp/media/map03/map_03_08.pdf

American Sugar Cane League. (2017). The Louisiana sugarcane industry production data 1975-2016. Retrieved November 16, 2017, from http://amscl.org/Images/Interior/sugar\%20industry\%20pamphlet/industryproduct iondata1975-2016.pdf

Amin, N. (2011). Use of bagasse ash in concrete and its impact on the strength and chloride resistivity. J. Mater. Civ. Eng., 23(5), 717-720. https://doi.org/10.1061/(ASCE)MT.1943-5533.0000227

Badger, P. C. (2002). Ethanol from cellulose: A general review. In J. Janick, \& A. Whipkey (Eds.), Trends in new crops and new uses (pp. 17-21). ASHS Press, Alexandria, VA.

Barrett, G. E., Alexander, P. D., Robinson, J. S., \& Bragg, N. C. (2016). Achieving environmentally sustainable growing media for soilless plant cultivation systems-A review. Scientia Horticulturae, 212, 220-234. https://doi.org/10.1016/j.scienta.2016.09.030

Cardona, C. A., Quintero, J. A., \& Paz, I. C. (2010). Production of bioethanol from sugarcane bagasse: Status and perspectives. Bioresource Technol., 101(13), 4754-4766. https://doi.org/10.1016/j.biortech.2009.10.097

Drummond, A. R. F., \& Drummond, I. W. (1996). Pyrolysis of sugar cane bagasse in a wire-mesh reactor. Ind. Eng. Chem. Res., 35(4), 1263-1268. https://doi.org/10.1021/ie9503914

Gu, M., Li, Q., Steele, P. H., Niu, G., \& Yu, F. (2013) Growth of 'Fireworks' gomphrena grown in substrates amended with biochar. J. Food Agric. Environ., 11(1), 819-821.

Guo, Y., Niu, G., Starman, T., Volder, A., \& Gu, M. (2018) Poinsettia growth and development response to container root substrate with biochar. Horticulturae, 4(1), 1-14. https://doi.org/10.3390/horticulturae 4010001

Hass, A., \& Lima, I. (2017). Effect of feed source and pyrolysis conditions on sugarcane bagasse biochar. Sugar Journal, 80(1), 31.

Ingram, L., Mohan, D., Bricka, M., Steele, P., Strobel, D., Crocker, D., ... Pittman, C. U. (2008). Pyrolysis of wood and bark in an auger reactor: Physical properties and chemical analysis of the produced bio-oils. Energy and Fuels, 22, 614-625. https://doi.org/10.1021/ef700335k

Jayasinghe, G. Y., Tokashiki, Y., Arachchi, I. D. L., \& Arakaki, M. (2010). Sewage sludge sugarcane trash based compost and synthetic aggregates as peat substitutes in containerized media for crop production. J. Hazard. Mater., 174(1-3), 700-706. https://doi.org/10.1016/j.jhazmat.2009.09.107 
Jhurree-Dussoruth, B., Kallydin, H., \& Bornes, Q. (2011). Investigation into low-cost medium for hardening of in vitro banana plantlets to promote adoption of disease-free plants. Acta Hort., 897, 489-490. https://doi.org/10.17660/ActaHortic.2011.897.69

Khomami, A. M., \& Moharam, M. G. (2013). Evaluation of sugar cane bagasse vermicompost as potting media on growth and nutrition of Dieffenbachia amoena 'tropic snow'. Int. J. Agron. Plant Prod., 4(8), 1806-1812.

Kilicaslan, I., Sarac, H. I., Ozdemir, E., \& Ermis, K. (1999). Sugar cane as an alternative energy source for Turkey. Energy Conversion and Management, 40(1), 1-11. https://doi.org/10.1016/S0196-8904(98)00103-4

Laird, D. A. (2008). The charcoal vision: A win-win-win scenario for simultaneously producing bioenergy, permanently sequestering carbon, while improving soil and water quality. Agronomy J., 100(1), 178-181. https://doi.org/10.2134/agronj2007.0161

Martin, C., Klinke, H. B., \& Thomsen, A. B. (2007). Wet oxidation as a pretreatment method for enhancing the enzymatic convertibility of sugarcane bagasse. Enzyme and Microbial Technol., 40, $426-432$. https://doi.org/10.1016/j.enzmictec.2006.07.015

Nigam, P. (1990). Investigation of some factors important for solid state fermentation of sugar cane bagasse for animal feed production. Enzyme and Microbial Technol., 12(10), 808-811. https://oi.org/10.1016/ 0141-0229(90)90156-K

Pandey, A., Soccol, C. R., Nigam, P., \& Soccol, V. T. (2000). Biotechnological potential of agro-industrial residues. I: Sugarcane bagasse. Bioresource Technol., 74(1), 69-80. https://doi.org/10.1016/S0960-8524(99) $00142-\mathrm{X}$

Payá, J., Monzó, J., Borrachero, M. V., Díaz-Pinzón, L., \& Ordóňez, L. M. (2002). Sugar-cane bagasse ash (SCBA): Studies on its properties for reusing in concrete production. J. Chem. Technol. Biotechnol., 77, 321-325. https://doi.org/10.1002/jctb.549

Peng, F., Ren, J. L., Xu, F., Bian, J., Peng, P., \& Sun, R. C. (2009). Comparative study of hemicelluloses obtained by graded ethanol precipitation from sugarcane bagasse. J. Agric. Food Chem., 57(14), 6305-6317. https://doi.org/10.1021/jf900986b

Sales, A., \& Lima, S. A. (2010). Use of Brazilian sugarcane bagasse ash in concrete as sand replacement. Waste Management, 30(6), 1114-1122. https://doi.org/10.1016/j.wasman.2010.01.026

Schmilewski, G. (2014). Producing growing media responsibly to help sustain horticulture. Acta Hortic., 1034(14), 299-305. https://doi.org/10.17660/ActaHortic.2014.1034.37

Stoffella, P. J., Li, Y., Calvert, D. V., \& Graetz, D. A. (1996). Soilless growing media amended with sugarcane filtercake compost for citrus rootstock production. Compost Sci. Util., 4(2), 21-25. https://doi.org/10.1080/ 1065657X.1996.10701826

Sun, Y., \& Cheng, J. (2002). Hydrolysis of lignocellulosic materials for ethanol production: A review. Bioresource Technol., 83(1), 1-11. https://doi.org/10.1016/S0960-8524(01)00212-7

Trochoulias, T., Burton, A. J., \& White, E. (1990). The use of bagasse as a potting medium for ornamentals. Scientia Horticulturae, 42(1-2), 161-167. https://doi.org/10.1016/0304-4238(90)90157-A

United States Department of Agriculture, Foreign Agricultural Service. (2017). Sugar: World markets and trade. Retrieved November 16, 2017, from https://apps.fas.usda.gov/psdonline/circulars/sugar.pdf

Vaughn, S. F., Kenar, J. A., Thompson, A. R., \& Peterson, S. C. (2013). Comparison of biochars derived from wood pellets and pelletized wheat straw as replacements for peat in potting substrates. Industrial Crops and Products, 51, 437-443. https://doi.org/10.1016/j.indcrop.2013.10.010

Webber, C. L. III, White, P. M. Jr., Petrie, E. C., Shrefler, J. W., \& Taylor, M. J. (2016). Sugarcane bagasse ash as a seedling growth media component. J. of Agricultural Sci., 8(1), 1-7. https://doi.org/10.5539/ jas.v7n12p1

Webber, C. L. III, White, P. M. Jr., Spaunhorst, D. J., \& Petrie, E. C. (2017a). Comparative performance of sugarcane bagasse and black polyethylene as mulch for squash (Cucurbita pepo L.) production. Journal of Agricultural Sci., 9(11), 1-9. https://doi.org/10.5539/jas.v9n11p1

Webber, C. L. III, White, P. M. Jr., Spaunhorst, D. J., \& Petrie, E. C. (2017b). Impact of sugarcane bagasse ash as an amendment on the physical properties, nutrient content and seedling growth of a certified organic greenhouse growing media. J. of Agricultural Sci., 9(7), 1-11. https://doi.org/10.5539/jas.v9n7p1 
White, P. M., Potter, T. L., \& Lima, I. M. (2015). Sugarcane and pinewood biochar effects on activity and aerobic soil dissipation of metribuzin and pendimethalin. Industrial Crops and Products, 74, 737-744. https://doi.org/10.1016/j.indcrop.2015.04.022

Xin, L., Kondo, R., \& Sakai, K. (2002). Biodegradation of sugarcane bagasse with marine fungus Phlebia sp. MG-60. J. Wood Sci., 48(2), 159-162. https://doi.org/10.1007/BF00767294

Zandersons, J., Gravitis, J., Kokorevics, A., Zhurinsh, A., Bikovens, O., Tardenaka, A., \& Spince, B. (1999). Studies of the Brazilian sugarcane bagasse carbonisation process and products properties. Biomass and Bioenergy, 17(3), 209-219. https://doi.org/10.1016/S0961-9534(99)00042-2

\section{Copyrights}

Copyright for this article is retained by the author(s), with first publication rights granted to the journal.

This is an open-access article distributed under the terms and conditions of the Creative Commons Attribution license (http://creativecommons.org/licenses/by/4.0/). 